\title{
Human Resources as
}

\section{a Strategic Partner in}

Multiunit-Restaurants

by Mark D. Fulford and

Cathy A. Enz
Despite the importance of human-resources issues to the success of chainrestaurant business, a close look at one such company indicates that humanresources managers are not yet party to firms' strategic decision making.

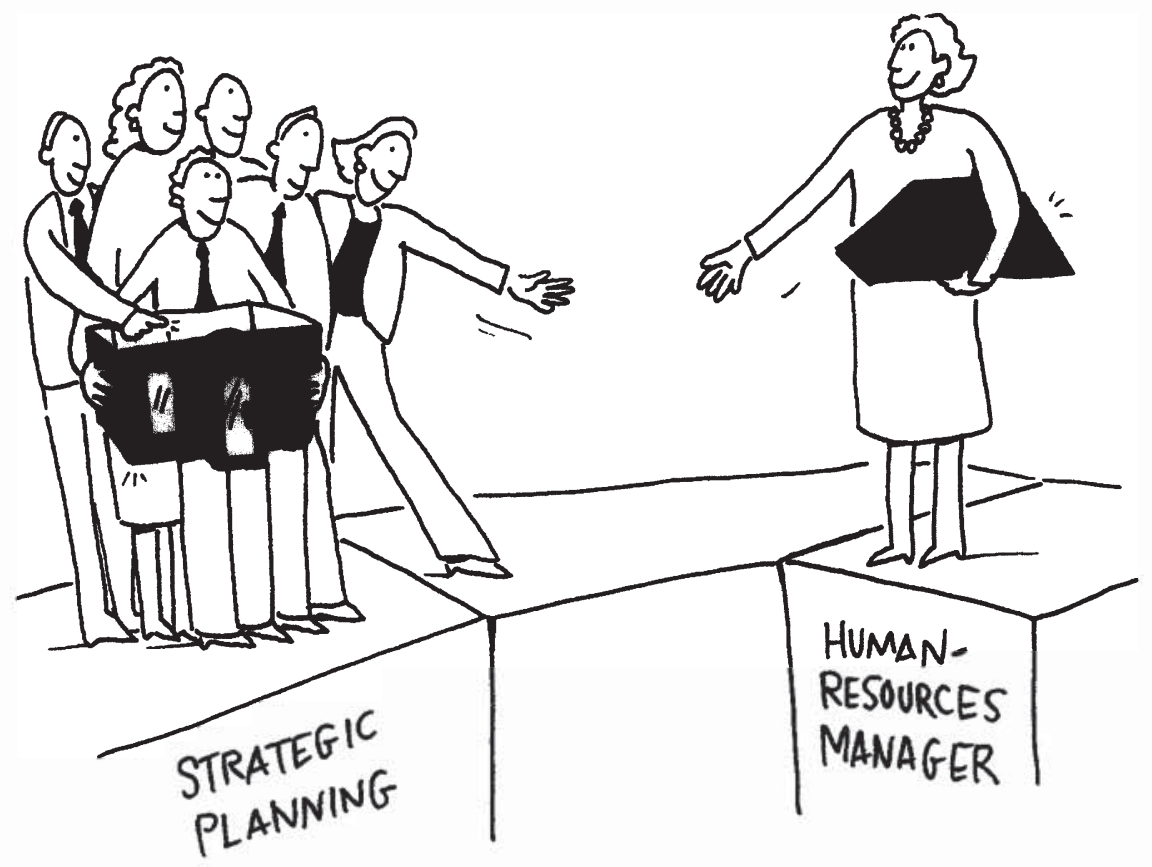

f your company's human-resources department is a bystander to overall competitive issues, you may be missing an opportunity to align customer needs with effective execution. Given the importance of employees to the success of multiunit-restaurant corporations, a strategic approach to the management of human resources is warranted as part of strategic planning. In this paper we will look at the view of

Mark D. Fulford, Ph.D., is an assistant professor of service-sector management at the College of Business Administration, California State University San Marcos. Cathy A. Enz, Ph.D., is an associate professor of management at the Cornell University School of Hotel Administration.

(C) 1995, Cornell University 


\section{Exhibit 1 Sample Profile}

\begin{tabular}{|c|c|c|c|c|}
\hline & $\begin{array}{c}\text { Restaurant } \\
\text { Managers } \\
n=137\end{array}$ & $\begin{array}{c}\text { Human- } \\
\text { Resources } \\
\text { Managers } \\
n=5\end{array}$ & $\begin{array}{c}\text { Corporate } \\
\text { Operations } \\
\text { Managers } \\
n=7\end{array}$ & $\begin{array}{c}\text { All Other } \\
\text { Corporate } \\
\text { Managers } \\
n=9\end{array}$ \\
\hline Age (years old) & 29 & 30 & 36 & 39 \\
\hline $\begin{array}{l}\text { Gender (percent) } \\
\text { Male } \\
\text { Female }\end{array}$ & $\begin{array}{l}76.6 \\
23.4\end{array}$ & $\begin{array}{l}60.0 \\
40.0\end{array}$ & $\begin{array}{l}86.0 \\
14.0\end{array}$ & $\begin{array}{l}90.0 \\
10.0\end{array}$ \\
\hline $\begin{array}{l}\text { Education (percent) } \\
\text { High School Grad } \\
\text { Some College } \\
\text { College Graduate } \\
\text { Graduate work or degre }\end{array}$ & $\begin{array}{c}9.5 \\
33.6 \\
48.9 \\
8.0\end{array}$ & $\begin{array}{c}0 \\
20 \\
60 \\
20\end{array}$ & $\begin{array}{c}0 \\
14 \\
43 \\
43\end{array}$ & $\begin{array}{c}0 \\
30 \\
60 \\
10\end{array}$ \\
\hline $\begin{array}{l}\text { Race (percent) } \\
\text { White } \\
\text { Other }\end{array}$ & $\begin{array}{c}98.5 \\
1.5\end{array}$ & $\begin{array}{l}80 \\
20\end{array}$ & $\begin{array}{c}100 \\
0\end{array}$ & $\begin{array}{l}90 \\
10\end{array}$ \\
\hline Years with Company & 4 & 4.6 & 5.7 & 5.1 \\
\hline
\end{tabular}

one multiunit quick-service restaurant corporation toward strategic human-resources management.

In some ways our study can be seen as a follow-up to Lombardi's article in these pages a year ago, in which he discussed issues of strategic planning but placed little emphasis on the contributions to strategic planning that the effective management of human resources can make. ${ }^{1}$

To determine whether the department is viewed as a strategic partner in overall restaurant competitiveness, we asked unit managers, human-resources managers, and operations managers at the corporate level of a single chain-restaurant company about the ability of the human-resources department to address critical problems of the overall operation. After we present our findings we discuss the factors

\footnotetext{
'Dennis J. Lombardi, "Chain-Restaurant Strategic Planning," Cornell Hotel and Restaurant Administration Quarterly, Vol. 35, No. 3 (June 1994), pp. 38-40.
}

in the industry that we suspect are responsible for them, and explain why we believe that the time has come to change the role of human resources.

\section{The Study}

We surveyed 158 managers of a Midwest-based chain of quickservice restaurants. The managers were grouped as follows: unit-level or store managers $(n=137)$, corporate human-resources managers $(n=5)$, corporate operations managers $(n=7)$, and other corporate managers $(n=9)$. See Exhibit 1 for a general profile of all the managers.

The study was conducted in two stages. In the first stage we developed a list of those strategic issues most critical to an organization's success. To do that we interviewed all corporate managers, including the president of the chain, and a random sample of unit-level managers. We asked them all what issues they deemed critical for success. Their answers were based on their experience in the industry and in the company itself; there was no prompting of any sort by the researchers. We asked probing questions to determine whether the issues that they identified had relevance to other operations and to ensure that the final list comprised the issues most important and least predictable, thus necessitating strategic planning. The most frequently identified critical issues were those that we included on the list.

The strategic issues on the list were:

- customer satisfaction (the ability to meet customers' needs);

- image management (the ability to enhance name recognition and company image);

- products and service (the ability to provide quality, service, cleanliness, and atmosphere);

- profitability (the ability to have a positive impact on the bottom line);

- attraction and retention (the ability to attract and retain quality employees); and

- low turnover (the ability to control employee turnover in general).

It is interesting that those last two issues have traditionally been perceived as being within the purview of the human-resources, or personnel, department.

In the second stage of data collection we administered a questionnaire to the same pool of managers as in the first phase, minus the company president; that is, to all corporate and unit-level managers in the chain. We listed the six strategic issues we had identified and asked the managers to indicate the degree to which the human-resources department influenced each of the critical issues and the degree to which the unit-level managers influenced each of the issues. Responses were on a scale of one ("no ability to affect") to seven ("greatest 


\section{Exhibit 2 Perceptions of ability to affect strategic issues}

\begin{tabular}{|c|c|c|c|c|c|c|}
\hline \multirow{3}{*}{ Respondent group: } & \multicolumn{4}{|c|}{$\begin{array}{c}\text { Non-traditional } \\
\text { human-resources issues }\end{array}$} & \multicolumn{2}{|c|}{$\begin{array}{c}\text { Traditional } \\
\text { human-resources issues }\end{array}$} \\
\hline & $\begin{array}{l}\text { Customer } \\
\text { needs }\end{array}$ & Image & Quality & Profit & $\begin{array}{l}\text { Attraction, } \\
\text { retention }\end{array}$ & Turnover \\
\hline & cos. & 8.8. & & & & \\
\hline Human-resources management & 3.18 & 3.17 & 3.65 & 3.42 & 4.79 & 4.92 \\
\hline Unit management $\dagger$ & 5.59 & 5.06 & 6.22 & 5.28 & 5.40 & 5.52 \\
\hline & & & & & & \\
\hline Human-resources management & 2.70 & 3.54 & 3.11 & 3.00 & 5.43 & 5.30 \\
\hline Unit management & 5.26 & 5.12 & 5.96 & 4.93 & 4.81 & 4.78 \\
\hline Huma & & & & & & ( \\
\hline Unit management & 5.21 & 5.04 & 5.96 & 4.96 & 4.79 & $\begin{array}{l}5.29 \\
4.75\end{array}$ \\
\hline & Withe & A & & 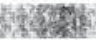 & & \\
\hline Human-resourc & 2.70 & 3.44 & 3.15 & 2.75 & 5.20 & 5.20 \\
\hline Unit management & 5.18 & 4.97 & 5.95 & 5.12 & 4.92 & 4.97 \\
\hline
\end{tabular}

Notes: Responses were on a scale of one ("no ability to affect") to seven ("greatest ability to affect").

*Perceptions about human-resources management.

tPerceptions about unit-level management.

ability to affect"). The response rate for unit-level managers was 83 percent, while virtually all corporate managers ( 96 percent) and all corporate human-resources managers responded. The high response rates demonstrate the value of the presurvey interviews and show the importance management attaches to analyzing critical success factors.

\section{The Findings}

Exhibit 2 summarizes the perceptions of the managers in this multiunit-restaurant corporation about the ability of those in the humanresources department and those who manage individual units to affect strategic issues.

To distinguish between the influence of each group on issues traditionally thought to be within the human-resources domain and those thought to be in other domains, we separated out "applicant attraction" and "employee turnover" issues (see Exhibit 2). If human-resources managers are seen as influencing only traditional human-resources issues, and unit managers are seen as influencing all issues, we can conclude that unit managers are considered strategic partners and humanresources managers are not.

Several findings are worth noting:

- Restaurant managers perceive the human-resources department as having little ability to affect nonhuman-resources strategic issues and only moderate ability to affect human-resources issues.

- Restaurant managers perceive themselves as being able to affect all the strategic issues (especially quality). In fact, they perceive themselves as having a greater ability to affect human-resources issues than the human-resources department.

- Human-resources managers perceive themselves as having little ability to affect strategic issues not related to human resources, while having a substantial ability to affect human-resources issues.

- Human-resources managers perceive restaurant managers as having a great ability to affect the non-human-resources strategic issues and a moderate to great ability to affect human-resources issues. In fact, human-resources managers consider restaurant managers to have almost the same ability to affect the humanresources strategic issues as they do themselves.

- Corporate operations managers and other corporate managers have perceptions similar to those of the human-resources managers.

- All respondent groups perceive restaurant managers as having a tremendous ability to affect quality, and they perceive humanresources managers as having little or no ability to affect customer needs.

There is almost unanimous belief among unit-level managers and corporate-level managers from all areas in this multiunit-restaurant organization that human-resources managers are not able to make substantial contributions toward shaping the strategic issues that will al- 
low the company to remain competitive in the marketplace. Humanresources managers are seen as having an impact only on issues directly related to employees. That narrow view is widely held within the multiunit-restaurant industry. ${ }^{2} \mathrm{We}$ will therefore call it the traditional view of human resources.

It is disconcerting that the human-resources managers themselves hold that view. They perceive themselves as having little impact on the non-human-resources strategic issues and only a moderate impact on traditional human-resources strategic issues.

\section{Reasons for the Traditional View}

The shared perception that humanresources managers are unable to have a positive impact on strategic issues outside their traditional domain is probably due to several factors inherent in the industry itself.

Organizational structure. In this restaurant chain, as in many others, the human-resources department is located at corporate headquarters; it would be prohibitively expensive to have a human-resources representative at each unit. Nonetheless, traditional human-resources activities, such as recruitment, selection, and training, are implemented at the individual units. Therefore it is the unit-level manager, not the human-resources manager, who is ultimately responsible for carrying out those activities.

In addition, because of the centralized human-resources department location and the decentralized implementation, the human-resources activities that are developed at the corporate level are only those projects and ideas that can be performed at all units. In other words,

${ }^{2}$ Cathy A. Enz and Mark D. Fulford, "The Impact of Human Resource Management on Organizational Success: Suggestions for Hospitality Educators," Hospitality and Tourism Educator, Vol. 5, No. 2 (February 1993), pp. 11-13. given the need for standardized human-resources programs, the corporate-level human-resources professionals do not develop programs and activities tailored for each individual unit. Quite the opposite, corporate managers design only programs that can be carried out by the company's most inexperienced or least competent unit manager; that is, to ensure universal implementation, the programs are targeted for the lowest common denominator. Owing to their distance from the market, corporate humanresources managers may become more involved in the creation and enforcement of policies and procedures than in market-driven or location-specific activities.

Manager turnover. The multiunit-restaurant industry is plagued by high rates of employee turnover, among both hourly employees and managers. In fact, some estimates are that annual managerial turnover runs as high as 100 percent. ${ }^{3}$ Along with the continual change in management comes a continual change in the degree of skill in carrying out human-resources activities at the unit level. That situation means that programs must be designed for the lowest common denominator. The result is human-resources programs that are generic, unsophisticated, rule-driven, and highly structured.

Focus on personnel administration. Because of structural and staffing constraints, many top-management teams at the corporate level demand a "template" for the management of human resources at the unit level (i.e., a "cookie-cutter" approach). That further narrows the contributions that can be made and the creativity that can be employed. Because those who demand the

${ }^{3}$ James M. McFillen, Carl D. Riegel, and Cathy A. Enz, "Why Restaurant Managers Quit (and How to Keep Them)," Cornell Hotel and Restaurant Administration Quarterly, Vol. 27, No. 3 (November 1986), pp. 37-43. template (corporate operations managers, for example) are in many cases not experts in humanresources management, they focus only on issues directly related to staffing and employee productivity: recruitment, selection, training, and retention. By specifying each activity individually, the organization, intentionally or not, limits the contributions made by humanresources managers.

The emphasis, then, is on personnel administration. But a frequently missed point is that personnel administration and humanresources management are not the same thing. ${ }^{4}$ Personnel administration is a functional, piecemeal approach, whereas human-resources management is a strategic, systematic, holistic approach.

For example, consider staffing: Under a personnel-administration approach, a unit that is having difficulty keeping workers might increase wages to attract more applicants. But that would raise labor costs and, all things being equal, reduce profits. Under a humanresource-management approach, however, the shortage would probably not have occurred at all, because the managers would have examined the local labor market and formulated a strategy to deal with the situation. If there was a shortage of teenage workers (who occupy most hourly positions in the industry), the unit would have a plan to recruit nontraditional sources of labor, such as retirees, the disabled, or mothers not working outside the home.

In the example above it's clear that a short-term, reactive, functional approach to human resources reduces the possibility of ever turning it into a strategic contributor.

\footnotetext{
${ }^{4}$ For further discussion, see: Enz and Fulford; and David Guest, "Personnel and HRM: Can You Tell the Difference?" Personnel Management, January 1989 , pp. 48-51.
} 
Strategic Human-resources Management

The traditional view of human resources in the multiunit-restaurant industry has been narrow; the focus has been on rule creation and personnel administration. Our study's results reinforce that view. We believe, therefore, that chain-restaurant organizations are missing important competitive opportunities and that they should broaden their view to include human-resources managers as strategic partners.

What it is. Strategic humanresources management is "the pattern of planned human resource deployments and activities intended to enable an organization to achieve its goals." The goals of most multiunit-restaurant organizations are to increase market share and to increase profitability. Effective human-resources management can facilitate the accomplishment of both those goals.

For example, to increase market share, certain knowledge is required of employees (especially those in marketing, sales, and operations). Strategic human-resources management would help the organization identify the employees or prospective employees who have a working knowledge of consumer trends and preferences and an understanding of the possible financial impacts.

Regarding profitability, we have already discussed one way strategic human-resources management can contribute to profits. The department can examine the labor market and alter recruitment strategies.

Another example: Assume the organization is considering expansion. Historically, human-resources managers have not been involved in decisions regarding the location of new units. The site selection is typically based mostly on market-pen-

\footnotetext{
SPatrick Wright and G. McMahan,"Theoretical Perspectives for Strategic Human Resource Management," Journal of Management, Vol. 18, No. 2 (1992), pp. 295-320.
}

etration information. The humanresources department is called in later to staff the new unit. When strategic human-resources management is used, however, the department is involved in selecting the site. It examines the local labor market and ascertains the relevant employment laws of the area. Issues such as the availability of labor and the existence of local labor laws could have an important impact on profits.

Why it is necessary. A broad view of human resources is necessary for another reason as well, because of changes in the industry itself. A few years ago the role of the multiunit-restaurant organization was narrow, and the traditional view of human resources was probably appropriate. But in 1992, for the first time in history, restaurant chains surpassed independent restaurants in revenues, and the growth of the chain-restaurant industry is expected to continue into the next century. ${ }^{6}$ Because the industry has expanded so greatly, the view of human resources must broaden.

To compete today, there is a greater need to adapt humanresources activities to local environments. Needs in different communities vary as their demographics vary. Moreover, local competitive pressures are on the rise. Labor pools, changing customer needs, and market competition are creating a turbulent, dynamic environment in which the industry must operate.

\section{Drastic Changes}

Considering the continuing changes in the industry, our finding that human-resources managers are not involved in strategic planning is

\footnotetext{
${ }^{6}$ Christopher C. Muller and Robert H. Woods, "An Expanded Restaurant Typology," Cornell Hotel and Restaurant Administration Quarterly, Vol. 35, No. 3 (June 1994), pp. 27-37; and Ronald N. Paul, "Status and Outlook of the ChainRestaurant Industry," Cornell Hotel and Restaurant Administration Quarterly, Vol. 35, No. 3 (June 1994), pp. 23-26.
}

somewhat surprising. Multiunitrestaurant organizations must have managers at both corporate headquarters and the individual units who have the knowledge, skills, and abilities necessary to adapt to changes in labor pools and customer demographics. Strategic humanresources management should be used to ensure that that is the case.

Labor pools. Owing to the oftcited changes in the demographics of the labor market, the industry must change its recruitment strategies. The National Restaurant Association estimates, for example, that over half of all restaurant employees are under the age of $25 .^{7}$ However, that cohort is expected to decline by about 2.1 million by the year $2000 .^{8}$ Multiunit-restaurant organizations must therefore do more to recruit employees from nontraditional sources. For example, McDonald's and other chain-restaurant companies have been targeting retirees and the disabled for years now.

Customer needs. Demographic trends affect not only the labor pools but the consumer base as well. As Paul states: "Consumer trends, affected by the evolving demographics of the population, are favorable. Growth in those segments of the population that either do not have time to cook or choose not to cook and can afford to eat out often is an obvious impetus to chain-restaurant expansion." As dining-out markets grow, there is an increasing pressure on restaurants of all types to meet an expanding set of consumer needs and expectations.

Market competition. Along with increased opportunities due to the changing lifestyles of consumers,

\footnotetext{
${ }^{7}$ National Restaurant Association, "Food Service and the Labor Shortage," NRA Current Issues Report, January 1986, p. 3.

${ }^{8}$ William B. Johnston, Workforce 2000: Work and Workers for the 21st Century (Indianapolis, IN: Hudson Institute; Washington, DC: U.S. Department of Labor, 1987), p. 146.

${ }^{9}$ Paul, p. 25.
} 
there are also increased challenges due to the competition among multiunit-restaurant organizations for the consumers' business. It is interesting that only one of the topten chain-restaurant companies in 1992 was also on the top-ten list in 1972. But, as Paul points out, "given the intense competition and the rapid pace of consumer shifts in preference, one cannot predict which companies will emerge as long-term winners." ${ }^{10}$

\section{Recommendations}

There are several steps that we believe will increase the likelihood that the evolving role of human resources will yield a competitive advantage.

Offer support. The chief executive officer or the corporate topmanagement team must not only decide to adopt strategic humanresources management but also demonstrate verbal and financial support of that decision. Like any organizational decision, if the top management doesn't support it, the employees won't, either. Given that the human-resources department has traditionally been viewed as a poor stepchild in an environment where operations is king, support from top management is crucial.

Increase interactions. Movement toward a view of strategic human-resources management and away from the stigma of personnel administration will be slow. Increasing the interactions between those in human resources and those in other functional areas will facilitate that transition, however. When human-resources representatives are allowed to sit in on marketing presentations, to become members of cross-functional teams or committees, and to become involved in strategic planning, other members of the organization will see the contributions they can make. That should

\footnotetext{
${ }^{10}$ Paul, pp. 25-26.
}

help legitimize the human-resources area as a strategic business partner.

Provide formal training. Simply increasing the frequency of interactions is not enough, however. Your human-resources managers must be capable of making significant contributions during those interactions. They must therefore be formally trained in not only human-resources management but also in marketing, finance, and so on.

Under the personnel-administration system, many of those in the human-resources department don't even have formal training in human-resources issues. Most often, they were administrative assistants moved into human resources because the area involved a lot of paperwork and administrative duties (the old rule-making role). With strategic human-resources management, however, an understanding of how business is conducted in a competitive marketplace is necessary.

The human-resources managers in our study themselves did not believe they had an impact on nonhuman-resources strategic issues. Perhaps that was because they were given no opportunities to get involved in other strategic issues. But another reason could be that they did not feel qualified to contribute. If your human-resources managers do not have the needed skills, you should invest in the development of those skills.

Develop career paths. Because of the need for human-resources representatives to understand how business is conducted, and because business is conducted in slightly different ways in each organization, all people in human resources should be exposed to the workings of their organizations. Moreover, the career path to human resources should go through operations.

Chains should consider adopting a policy of not giving a managerial position in human resources to someone until that person has had a minimum amount of experience at the operations level. That will facilitate the strategic-planning process, because the other members of your strategic-planning team will know that the human-resources managers understand operational considerations and can make substantive recommendations on issues involving people. Operations experience will give your human-resources team the credibility and confidence to contribute to the overall organization. If necessary, send your human-resources managers into the field, even if only for a brief time, to expose them to daily operational issues and to legitimize in the eyes of their colleagues their ability to make important decisions.

\section{Too Restrictive}

Our study showed that many limiting beliefs continue to exist about the roles and abilities of humanresources managers. The need for multiunit-restaurant corporations to engage in strategic human-resources management is driven by a tougher, more competitive marketplace than that of the past. Because of increased competition, no multiunitrestaurant organization can afford to limit the activities of its humanresources department to personnel administration. No organization can afford to have human-resources managers who are not customerdriven, are not cost-aware, or do not understand the ability to manage people in such a way that allows the organization to achieve its mission or goals.

Only when human-resources managers understand how business is conducted in the multiunitrestaurant organization and are given the opportunity to demonstrate that understanding will they truly become partners in the strategic management of the firm. Ca 